\title{
Endosulfine, endogenous ligand for the sulphonylurea receptor: isolation from porcine brain and partial structural determination of the $\alpha$ form
}

\author{
A. Virsolvy-Vergine ${ }^{1}$, G.Salazar ${ }^{1}$, R.Sillard ${ }^{2}$, L.Denoroy ${ }^{3}$, V.Mutt ${ }^{2}$, D. Bataille ${ }^{1}$ \\ ${ }^{1}$ Institut National de la Santé et de la Recherche Médicale U376, CHU Arnaud de Villeneuve, Montpellier, France \\ ${ }^{2}$ Department of Medical Biochemistry and Biophysics, Laboratory of Biochemistry, Karolinska Institute, Stockholm, Sweden \\ ${ }^{3}$ Centre National de la Recherche Scientifique, Service Central d'Analyse, Vernaison, France
}

Summary Anti-diabetic sulphonylureas act via high affinity binding sites coupled to K-ATP channels. Endosulfine, an endogenous ligand for these binding sites, was shown to exist in two molecular forms, $\alpha$ and $\beta$, in both the pancreas and the central nervous system. We describe here the isolation, and partial structural characterization of $\alpha$ endosulfine derived from porcine brains by means of a series of chromatography runs and gel electrophoresis. Porcine $\alpha$ endosulfine is a protein with a molecular mass of 13,196 daltons as determined by mass spectrometry and which is N-terminally blocked. Tryptic digestion followed by separation of the fragments by HPLC and automated Edman degradation yielded a total of 72 amino acids in four partial sequences. Comparison of these sequences with that present in the $\mathrm{Na}$ tional Biomedical Research Foundation protein data bank indicated a $82 \%$ identity with a 112 -amino acid protein with a molecular mass of 12,353 daltons called 'cyclic AMP-regulated phosphoprotein-19', isolated from the bovine brain as a substrate for protein kinase A. [Diabetologia (1996) 39: 135-141]

Key words Endosulfine, sulphonylurea, receptor, endogenous ligand.
Anti-diabetic sulphonylureas are commonly used for the management of non-insulin-dependent diabetes mellitus, thanks to their hypoglycaemic action [1]. It is now well-established that their anti-diabetic properties are primarily mediated by their ability to stimulate insulin secretion from the pancreatic beta cells via high affinity binding sites, or receptors $[2,3]$. These receptors are linked to ATP-dependent potassium channels (K-ATP channels) $[4,5]$ which are also involved in glucose-induced insulin secretion $[6$, 7]. Sulphonylurea receptors have also been character-

Received: 31 March 1995 and in revised form: 13 July 1995

Corresponding author: Dr. A. Virsolvy-Vergine, INSERM U376, CHU Arnaud de Villeneuve, Batiment INSERM, 371, Rue du Doyen Gaston Giraud, F-43295 Montpellier Cedex 5, France

Abbreviations: BSA, Bovine serum albumin; PAGE, polyacrylamide gel electrophoresis; ARPP-19, cyclic AMP-regulated phosphoprotein-19; TFA, trifluoroacetic acid; PTH, phenylthiohydantoin; CNS, central nervous system. ized in the central nervous system (CNS) [8,9]. These data indicated the existence of an endogenous ligand for these receptors [10]. We have previously shown that such an endogenous molecule [10], which we have named 'endosulfine', indeed exists in the rat brain. Endosulfine is of peptidic nature and is present in the CNS in two molecular forms, which differ in their isoelectric points [11]; they are termed $\alpha$ and $\beta$ endosulfines, the $\beta$ form being more basic. Both $\alpha$ and $\beta$ endosulfines equally recognize the sulphonylurea receptors present either in the CNS or in the beta cells. Highly purified $\beta$ endosulfine has been shown to stimulate insulin secretion from beta-cell lines in culture, at concentrations which were active on the sulphonylurea receptors [11].

In the present report, we describe the isolation from porcine brain of $\alpha$ endosulfine, a protein with an apparent molecular mass on SDS-PAGE of $19 \mathrm{ki}-$ lodaltons $(\mathrm{kDa})$. We have obtained pure $\alpha$ endosulfine in amounts which allowed us to determine its molecular mass by mass spectrometry and to obtain significant information on its primary structure. The 
$\alpha$ form of endosulfine was $\mathrm{N}$-terminally blocked and its tryptic digestion yielded several fragments, the amino acid sequence of which has been partially determined. From this partial structure, it appears that $\alpha$ endosulfine is the porcine equivalent of, or is closely related to, a protein of similar size, previously isolated from bovine brain as a substrate for cyclic AMP-dependent protein kinase.

\section{Materials and methods}

Sulphonylureas. Glibenclamide was provided by the Guidotti Laboratory (Pierre Fabre Laboratories, Castres, France). $\left[{ }^{3} \mathrm{H}\right]$ glibenclamide with a specific activity of $48-51 \mathrm{Ci} / \mathrm{mmol}$ was purchased from Du Pont (Les Ulis, France).

Binding assay. Binding studies were conducted as previously described $[8,11]$ with a membrane homogenate prepared from 200 to $300 \mathrm{~g}$ male Wistar rat cortex. Freshly prepared membranes $(0.4 \mathrm{mg}$ of protein per $\mathrm{ml})$ were incubated for $1 \mathrm{~h}$ at room temperature with $0.1 \mathrm{nmol} / 1\left[{ }^{3} \mathrm{H}\right]$ glibenclamide in $50 \mathrm{mmol} / \mathrm{l}$ Tris- $\mathrm{HCl}, \mathrm{pH} 7.5$ with no addition of albumin or protease inhibitors, in the presence of unlabelled sulphonylurea or chromatographic fractions. Bound and free glibenclamide were separated by filtration under vacuum on $\mathrm{GF} / \mathrm{B}$ glass fibre filters (Whatman, Maidstone, Kent, UK) after addition of 2 volumes of Tris buffer at $4^{\circ} \mathrm{C}$ and the filters were washed twice with the same cold buffer; radioactivity was counted after addition of liquid scintillation medium (PCS; Amersham, Les Ulis, France).

Tissue extraction and preliminary fractionation. Porcine brains were removed within $30 \mathrm{~min}$ after death, immediately boiled in water for $10 \mathrm{~min}$, frozen and kept at $-25^{\circ} \mathrm{C}$ until their extraction using the heat-coagulation acid-extraction method developed for peptides [12]. The peptide concentrate obtained was dissolved in water and 4.5 volumes of isopropanol was added. The precipitated fraction of larger polypeptide ( $\mathrm{F} 0$ ) was filtered off and the same volume of isopropanol was added to the filtrate. After chilling to $-20^{\circ} \mathrm{C}$, the next precipitate ( $\mathrm{F} 1$ ) was collected by filtration at $-20^{\circ} \mathrm{C}$ [13]. This fraction $\mathrm{F} 1$ was further purified by different chromatographic systems.

\section{Purification steps}

Cation exchange chromatography. A $25 \times 400 \mathrm{~mm}$ mediumpressure column (Pharmacia Biotech, Orsay, France) filled with SP-Sepharose fast flow (Pharmacia) equilibrated in $10 \mathrm{mmol} / \mathrm{l}$ ammonium-acetate containing $20 \%$ ethanol, $\mathrm{pH}$ 6.15 , was run at $8 \mathrm{ml} / \mathrm{min}$ using a preparative liquid chromatography apparatus (Waters-Millipore, Milford, Conn., USA). F1 fraction $(0.5 \mathrm{~g})$ was dissolved in $50 \mathrm{ml} 10 \mathrm{mmol} / \mathrm{l}$ ammoniumacetate and loaded at $8 \mathrm{ml} / \mathrm{min}$ on the column which was eluted at the same flow rate using a 50 -min linear gradient from $10 \mathrm{mmol} / 1$ to $500 \mathrm{mmol} / 1 \mathrm{ammonium}$-acetate containing $20 \%$ ethanol, $\mathrm{pH}$ 6.15. One-minute fractions were collected and a 1:20 sample was set apart from each fraction for the binding assay; the remaining samples were lyophilized.

Reversed phase HPLC. Three columns were run successively: a $\mathrm{C} 8$, a $\mathrm{C} 18$ and a CN column (SFCC, Société Française de Chromato Colonne, Neuilly-Plaisance, France). Solvents were de- livered by two model 6000A pumps (Waters-Millipore) and the gradient was monitored by a gradient controller (WatersMillipore). Packing, column size, solvents and conditions are detailed in the legends to the figures. One-minute fractions were collected and aliquots (1:12 of the total volume) were taken for the binding assay. Active fractions were pooled and applied to the next column, either directly or after lyophilization. During the gradient, the ultra violet absorbance at $280 \mathrm{~nm}$ was detected using a variable wavelength detector (LDC analytical, Riviera Beach, Calif., USA).

Gel filtration chromatography. Gel filtration separations were carried out on a $10 \times 400 \mathrm{~mm}$ glass column (Pharmacia) filled with Sephadex G-50 gel (Pharmacia). The column was equilibrated with the elution medium $(0.2 \mathrm{~mol} / \mathrm{l}$ acetic acid) at a flow rate of $10 \mathrm{ml} / \mathrm{h}$. Fractions of $500 \mu \mathrm{l}$ were collected and analysed in the binding assay; active fractions were analysed for their protein content by polyacrylamide gel electrophoresis.

Polyacrylamide gel electrophoresis and electroelution. The SDS-PAGE method described by Laemmli [14] was used. Proteins were separated on $20 \%$ acrylamide gels and detected after electrophoresis by Coomassic Blue G-250 staining. Gels were calibrated using the following molecular weight markers: myosin $\left(M_{r} 205,000\right)$, $\beta$-galactosidase $\left(M_{r} 116,000\right)$, phosphorylase $B\left(M_{r} 97,400\right)$, bovine serum albumin $\left(M_{r} 66,000\right)$, ovalbu$\min \left(M_{r} 45,000\right)$ carbonic anhydrase $\left(M_{r} 24,000\right)$, soybean trypsin inhibitor $\left(M_{r} 20,100\right)$, and $\alpha$-lactalbumin $\left(M_{r} 14,200\right)$.

The electroelution of $\alpha$ endosulfine was conducted from a preparative SDS-PAGE separation of active fractions deriving from a semi-preparative $\mathrm{CN}$ column; proteins were visualized by a short (3-min) Coomassie Blue staining; the band corresponding to $\alpha$ endosulfine was excised. Electroelution was performed using a Bio-Rad SA Model 422 electroeluter (Bio-Rad $\mathrm{SA}$, Ivry/Seine, France) for $2 \mathrm{~h}$ at $9 \mathrm{~mA}$ per tube, in the following elution buffer: $25 \mathrm{mmol} / 1$ Tris, $192 \mathrm{mmol} / 1$ glycine, $\mathrm{pH} 8.5$. The eluted protein was then purified on an analytical reversed phase $\mathrm{CN}$ column (SFCC); elution was run at $1.5 \mathrm{ml} / \mathrm{min}$ in $0.1 \%$ trifluoroacetic acid (TFA) with a 40 -min linear gradient from 10 to $50 \%$ acetonitrile. One-minute fractions were collected and their purity was checked by PAGE; fractions displaying homogeneity were then analysed for their primary structure.

Experiments on protein stickiness. We used NAP-5 columns (Pharmacia) filled with Sephadex G-25, usually used for rapid separation or sample desalting. A total of $30 \mu \mathrm{g}$ of bovine serum albumin (BSA, fraction V; Sigma Chimie, L'isle d'Abeau Chesnes, France), $100 \mu \mathrm{g}$ of $\gamma$-globulins (fractions II, III, Sig$\mathrm{ma}$ ), or $30 \mu \mathrm{g}$ of purified $\alpha$ endosulfine were applied separately on the column in the presence of $0.1 \mathrm{nmol} / 1\left[{ }^{3} \mathrm{H}\right]$ glibenclamide in a total volume of $200 \mu \mathrm{l}$. Elution was performed with $10 \mathrm{ml}$ of $50 \mathrm{mmol} / \mathrm{l}$ Tris-HCl, $\mathrm{pH} 7.5$, using 250- $\mu$ l fractions. Radioactivity was detected in fraction samples by liquid scintillation beta counting and protein concentrations were determined using the Bradford reagent protein assay [15] using BSA as standard. We analysed $0.1 \mathrm{nmol} / 1$ of $\left[{ }^{3} \mathrm{H}\right]$ glibenclamide as a control under the same conditions.

Mass spectrometry and amino-acid sequencing. These analyses were performed at the CNRS Central Analysis Service according to the following procedures:

Mass spectrometry. Molecular mass was determined by electrospray ionisation using a Hewlett Packard 5989 MS Engine (Hewlett Packard, Palo Alto, Calif., USA) with a solvent containing $1 \%$ acetic acid in methanol/water (50/50). 
Trypsin cleavage. Digestion with tosyl-L-phenylalanine chloromethyl ketone (TPCK) treated trypsin (Worthington, Freehold, N.J., USA) was carried out at $37^{\circ} \mathrm{C}$ for $4 \mathrm{~h}$. After acidification with TFA, peptides were separated by reversed phase HPLC on a Brownlee Aquapore RP300 C4 column as previously described [16].

$N$-terminal sequence determination. The sequence determinations were performed by Edman degradation using a $470 \mathrm{~A}$ Applied Biosystems-Perkin Elmer gas phase sequencer (Norwalk, Conn., USA) [17, 18]. Phenylthiohydantoin (PTH) amino acids were identified on line with a $120 \mathrm{~A}$ Applied Biosystems PTH-analyser by reversed phase HPLC using a Brownlee PTH-C18 cartridge $(2.1 \times 220 \mathrm{~mm})$. The samples were sequenced using polybrene-coated glass fibre as support; the sequencing was performed using the 03RPTH program provided by Applied Biosystems, with slight modifications.

Search in data banks. Amino acid sequences obtained from $\alpha$ endosulfine were compared to the sequences present in the National Biomedical Research Foundation (NBRF) protein data bank using the BLAST and FASTA programs via the BISANCE service [19].

\section{Results}

Purification of $\alpha$ endosulfine from porcine brain. We have previously shown that endosulfine may be extracted by the heat-coagulation acid-extraction method [12]. The main problem encountered during endosulfine purification was related to the extraction scale because of the relatively low quantities of endosulfine present in the brain. The extraction of several hundred $\mathrm{kg}$ of porcine brain [13] gave us the opportunity of testing different fractions resulting from this extraction. $\alpha$ and $\beta$ endosulfine were mainly present in the F1 fractions. $\alpha$ endosulfine, the most concentrated form, was purified first from this F1 fraction using a series of cation exchange and reversed phase chromatography methods. Several runs were performed in order to obtain enough $\alpha$ endosulfine for its structural characterization. Figure 1 represents a typical purification procedure: $0.5 \mathrm{~g}$ of fraction $\mathrm{F} 1$ was run on the SP-sepharose column (Fig. 1 A). Active fractions were lyophilized, pooled and purified on the preparative $\mathrm{C} 8$ column (Fig. 1 B). The next purification step was a semi-preparative C18 column (Fig. $1 \mathrm{C}$ ). The active fractions from three $\mathrm{C} 18$ runs were pooled and fractionated so as to perform further purification steps by analytical chromatography runs. The next step was an analytical CN column (Fig. 2). Active fractions were analysed on gel electrophoresis. In fractions 9 to 12 corresponding to the binding peak (Fig. 2A), a main protein band was visible in PAGE, with an apparent molecular mass of around $19 \mathrm{kDa}$ (Fig. 2B). This protein was present in every fraction containing the $\alpha$ endosulfine activity (data not shown). Table 1 gives quantitative data on the main steps of $\alpha$-endosulfine isolation. It was observed that foreign proteins present in fractions from early
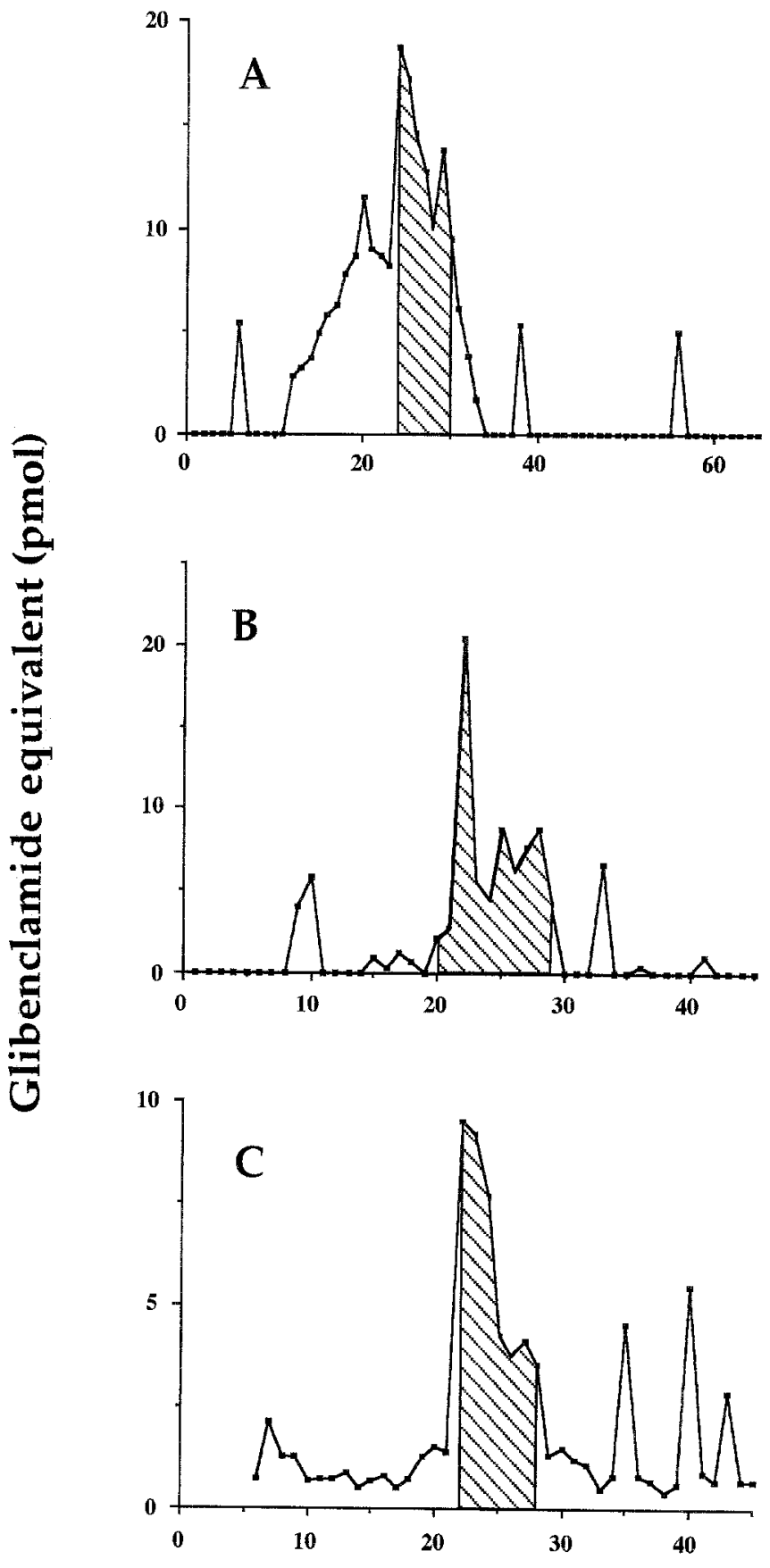

Fraction number

Fig.1A-C. Series of three chromatographic steps for purification of $\alpha$ endosulfine present in fraction $F 1$ from porcine brain extract. Chromatographic fractions were assayed for their ability to interact with the central sulphonylurea receptors. (A) First step, cation exchange chromatography of $0.5 \mathrm{~g}$ of fraction F1. Fractions 24-30, corresponding to the hatched zone, were loaded on the next column after lyophilization. (B) The second step used a $1.0-\mathrm{cm}$ internal diameter $\times 25 \mathrm{~cm}$ reversed phase $\mathrm{C} 8$ column equilibrated with $1 \%$ TFA-diethylamine, $\mathrm{pH} 2.5$ eluted with a linear gradient of $20-50 \% \mathrm{CH}_{3} \mathrm{CN}$ in $45 \mathrm{~min}$ at $6 \mathrm{ml} / \mathrm{min}$. Fractions 20-29 (hatched zone) were loaded on the next column after lyophilization. (C) The third step used a $1.0-\mathrm{cm}$ internal diameter $\times 25 \mathrm{~cm}$ reversed phase $\mathrm{C} 18$ column equilibrated with $10 \mathrm{mmol} / 1$ Tris- $\mathrm{HCl}, \mathrm{pH} 7.5$ eluted with a linear gradient of $10-50 \% \mathrm{CH}_{3} \mathrm{CN}$ in $50 \mathrm{~min}$ at $6 \mathrm{ml} / \mathrm{min}$. Fractions 22-28 were pooled and applied to the next column after evaporation of acetonitrile 

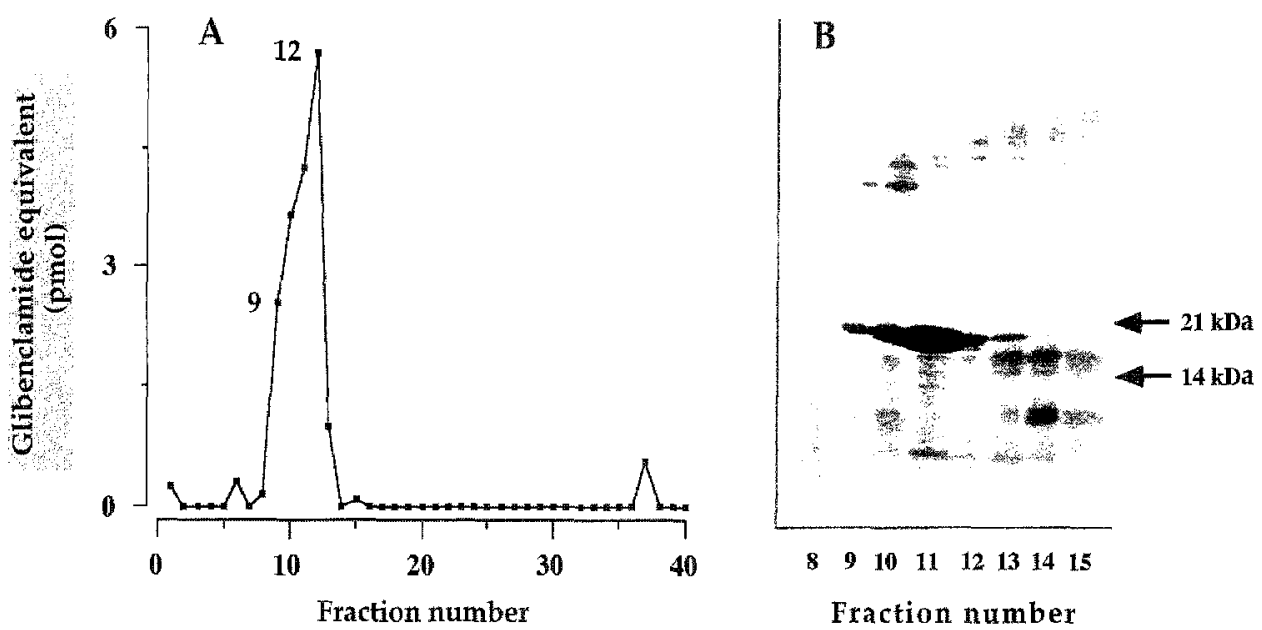

$\begin{array}{lllllllll}8 & 9 & 10 & 11 & 12 & 13 & 14 & 15\end{array}$

Fraction number
Fig. 2 A, B. Analytical run on a $0.25-\mathrm{cm}$ internal diameter $\times 25 \mathrm{~cm}$ reversed phase $\mathrm{CN}$ column of active fractions from C18 (22 to 28). The column was equilibrated with $0.1 \%$ TFA and eluted with a linear gradient of $10-50 \% \mathrm{CH}_{3} \mathrm{CN}$ in $40 \mathrm{~min}$ at $1.5 \mathrm{ml} / \mathrm{min}$. (A) Analysis of the chromatographic fractions by their ability to interact with the sulphonylurea receptor. (B) Analysis by SDS-PAGE followed by Coomassie blue staining of fractions $8-15$

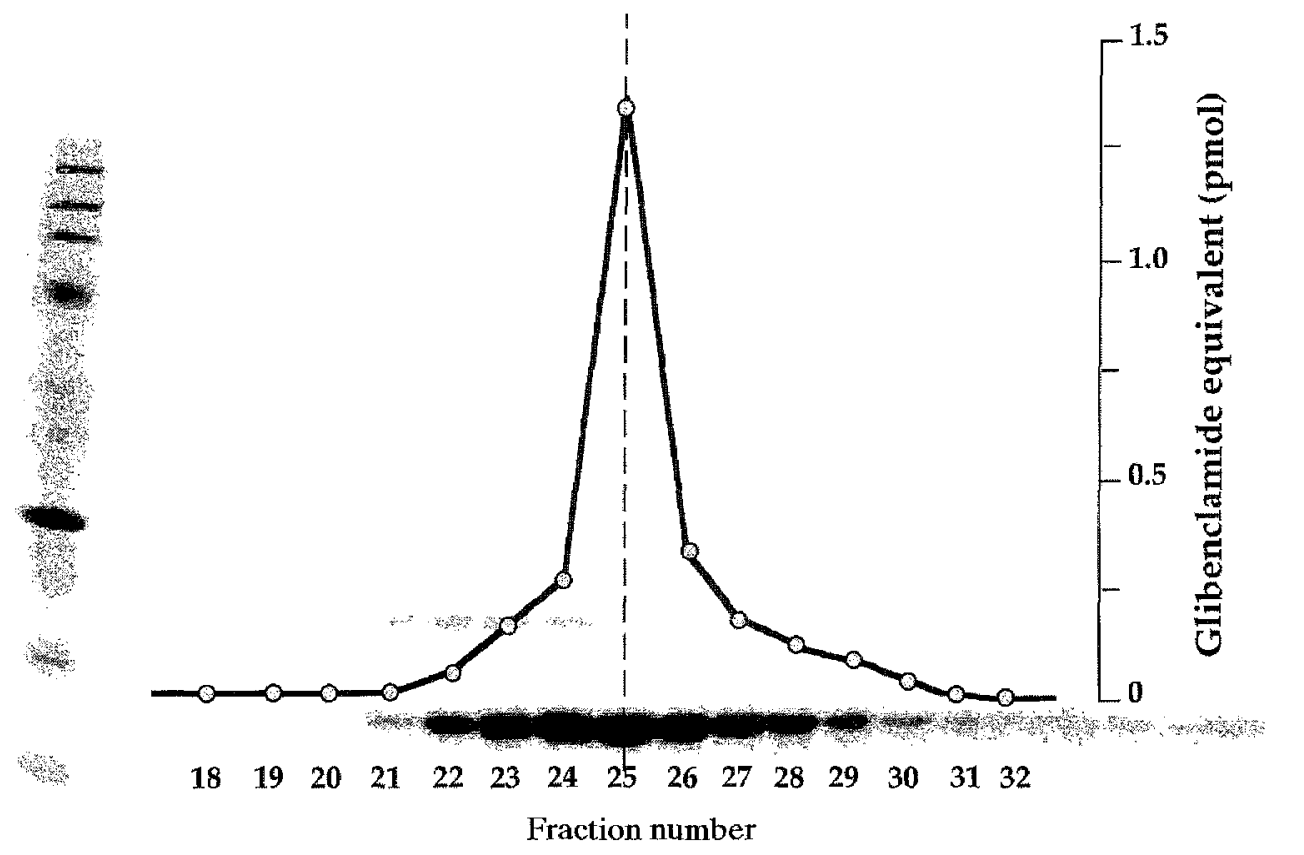

Fig. 3. Isolation of the $19 \mathrm{kDa}$ protein by gel filtration chromatography on Sephadex G-50. Superimposition of the protein detected by SDS-PAGE in the chromatographic fractions and their activity in the binding assay on sulphonylurea receptors

steps significantly interfered with glibenclamide binding, increasing artificially the apparent activity of these fractions. Accordingly, the increase in specific activity as well as the yields are certainly better than that available from Table 1.

In order to confirm the correlation between the presence of this protein and the endosulfine activity, fractions from the C18 column containing $\alpha$ endosulfine were run on a semi-preparative $\mathrm{CN}$ column under the conditions described in Figure 2. We obtained 26-pmol glibenclamide equivalents of $\alpha$ endosulfine. The active fractions were enriched in the 19kDa protein (Fig. 2). Further purification by gel filtration of $\mathrm{CN}$ fractions led us to obtain the $19-\mathrm{kDa}$ at a high degree of purity. Figure 3 shows that the activity of $\alpha$ endosulfine on the sulphonylurea receptor and the detection of the $19 \mathrm{kDa}$ protein on gel electrophoresis were superimposable. This strongly suggested that the binding activity was intrinsic to this
Table 1. Quantitative data on the different steps of purification of porcine $\alpha$ endosulfine. The data are given for $0.5 \mathrm{~g}$ of F1 fraction

\begin{tabular}{lclll}
\hline Step & $\begin{array}{l}\text { Protein } \\
\text { (mg) }\end{array}$ & $\begin{array}{l}\text { Activity } \\
\text { (pmol gli- } \\
\text { benclamide } \\
\text { equivalent) }\end{array}$ & $\begin{array}{l}\text { Yield } \\
(\%)\end{array}$ & $\begin{array}{l}\text { Specific } \\
\text { activity } \\
\text { (pmol/mg } \\
\text { protein) }\end{array}$ \\
\hline SP-Sepharose & 219 & 100 & ND & 0.45 \\
HPLC-1 (C8) & 170 & 70 & 70 & 0.41 \\
HPLC-2 (C18) & 40 & 25 & 36 & 0.625 \\
HPLC-3 (CN) & 14.4 & 17 & 68 & 1.18 \\
\hline
\end{tabular}

$\mathrm{ND}$, Not determined

protein. However, since it is well known that sulphonylureas display strong adsorption to some proteins such as albumin, we tested whether $\left[{ }^{3} \mathrm{H}\right]$ glibenclamide might stick to the $19-\mathrm{kDa}$ protein in view of a possible artifact leading to misinterpretation of the binding data. 


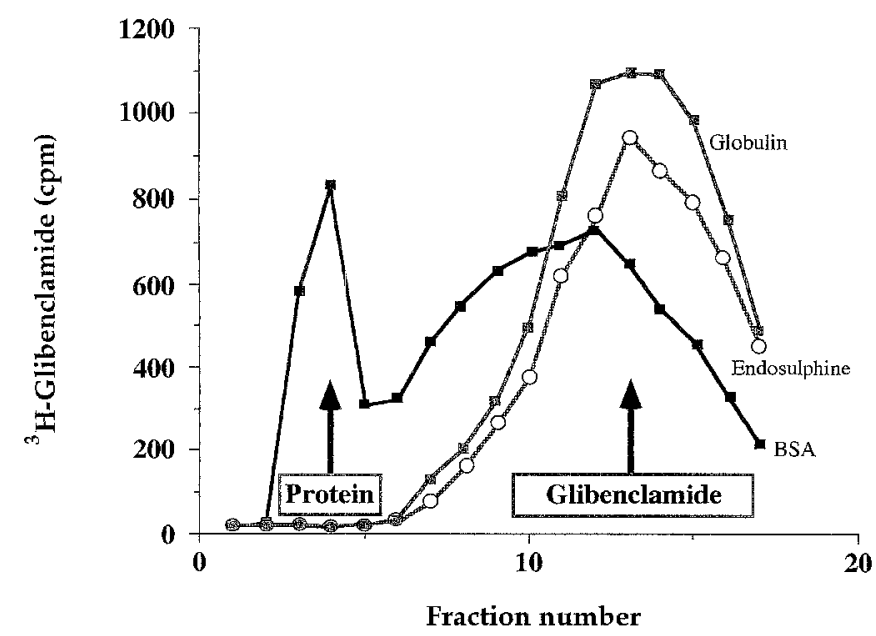

Fig. 4. Elution profile on NAP-5 (Sephadex G-25) column of $\left[{ }^{3} \mathrm{H}\right]$ glibenclamide in the presence of BSA ( $\square$ ), globulin (囉) and $\alpha$ endosulfine $(O)$. The arrows indicate the elution volume of the proteins and free labelled glibenclamide

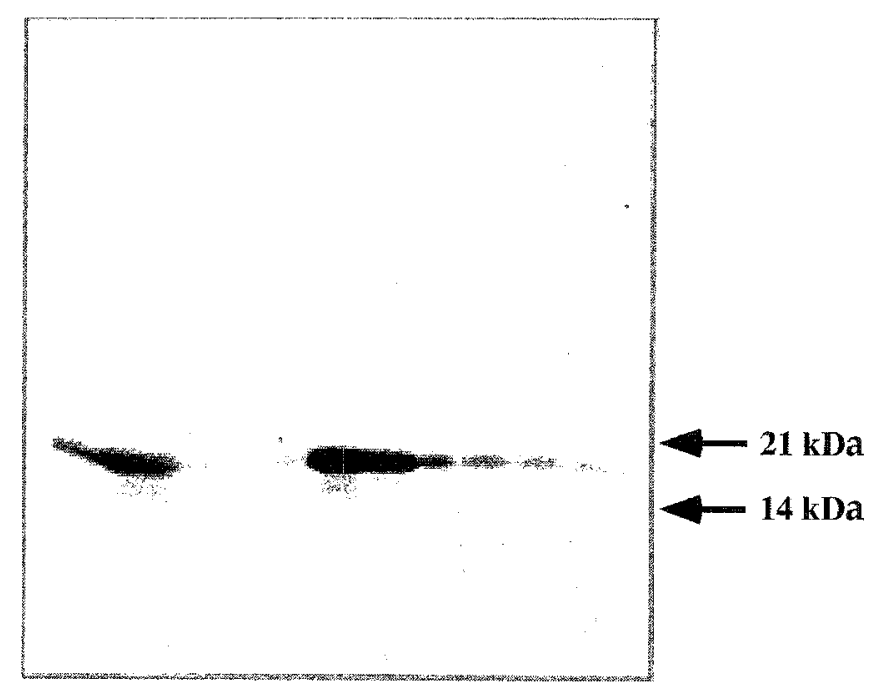

\section{Before $\quad \begin{array}{lllllll}16 & 17 & 18 & 19 & 20 & 21 & 22\end{array}$ \\ HPLC Fraction number}

Fig. 5. Control by SDS-PAGE and Coomassie blue staining of the purity of the electroeluted $19 \mathrm{kDa}$ protein after chromatography on an analytical reversed phase $\mathrm{CN}$ column in the conditions described in Figure 2

Do sulphonylureas stick to endosulfine? To answer this question, we used NAP-5 (Sephadex) columns which rapidly separate proteins and ionic molecules, with no interaction with the gel phase. The retention times of $\left[{ }^{3} \mathrm{H}\right]$ glibenclamide and proteins were very different (Fig. 4), the proteins (BSA, globulin and endosulfine) eluting in fractions 3 and 4 , whereas $\left[{ }^{3} \mathrm{H}\right]$ glibenclamide eluted in fractions 7 to 16 . In the presence of BSA, a significant part of the radioactivity $(21 \%)$ eluted in the protein volume, indicating that $\left[{ }^{3} \mathrm{H}\right]$ glibenclamide sticks to albumin under our experimental conditions. In contrast, no such obser- vations were made when either globulin or $\alpha$ endosulfine were run with labelled glibenclamide. This showed that sulphonylureas did not stick to $\alpha$ endosulfine. This indicates that the observed activity of $\alpha$ endosulfine was due to an actual binding of the molecule to the sulphonylurea receptor displacing the tracer and was not the result of an artifact related to a possible molecular interaction between the protein and labelled glibenclamide.

Isolation of $\alpha$ endosulfine. The last purification step was an electroelution of the protein from a preparative gel electrophoresis of active fractions from the $\mathrm{CN}$ column. The electroeluted protein was purified on an analytical $\mathrm{CN}$ column and its purity was checked by PAGE (Fig. 5). Fractions 18, 19 and 20, displaying the presence of the $19 \mathrm{kDa}$ protein alone, were analysed for the primary structure of the protein. It was not possible to test these fractions in the binding assay because of the presence of SDS. Indeed, the remaining SDS strongly associated with the protein-induced artifactual activities both by interfering with the binding of the tracer and by partial solubilization of the membranes.

Structural features. The mass spectrometry determination gave a molecular mass of 13,196 . No amino acid was detected after several cycles of Edman degradation of the protein, indicating that the $\mathrm{N}$-terminal was blocked. A tryptic digestion of the protein yielded several fragments which were separated by HPLC. The analysis of one of these fragments gave the following sequence: Tyr-Phe-Asp-Ser-Gly-AspTyr-Asn-Met-Ala-Lys.

After data bank interrogation, it appeared that this sequence corresponds exactly to a moiety present in a $19 \mathrm{kDa}$-protein, isolated by Girault et al. [20,21] and named cyclic AMP regulated phosphoprotein-19 (ARPP-19). Further analysis of the fragments led us to obtain the determination of 72 amino acids of the protein. A comparison of the primary structure of porcine $\alpha$ endosulfine known so far with that of bovine ARPP-19 is given in Figure 6.

\section{Discussíon}

Anti-diabetic sulphonylureas act primarily via binding sites coupled to K-ATP channels which are present in a limited number of target tissues including insulin-secreting pancreatic beta cells, heart cells and various areas of the CNS. The latter localization of these sites and of K-ATP channels led us to explore the possibility that, in this specific region of the organism, relatively isolated from the rest of the body, an endogenous ligand exists in the vicinity of the recognition system. We have shown that such a ligand does exist, in the form of two molecules of peptidic 


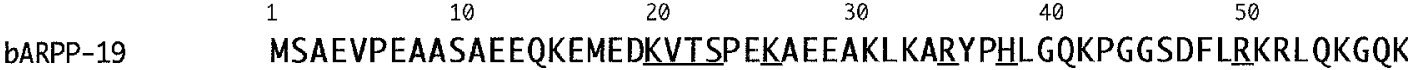 \\ pa-endosulfine EGILPERAEEAK AKYPSLGQKPGGSDFLMKR QK}

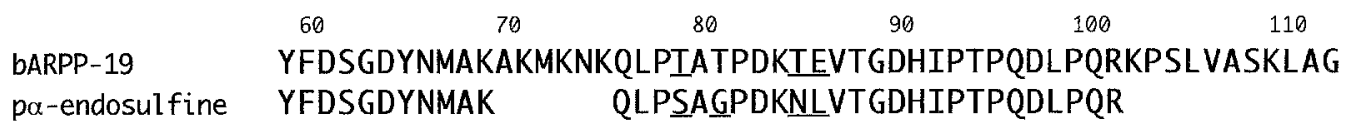

Fig. 6. Comparison between the sequences of bovine ARPP19 (bARPP-19) published previously [21] and the amino acid sequences determined for porcine $\alpha$ endosulfine ( $\mathrm{p} \alpha$-endosulfine). The differences between the two proteins are underlined

nature that we have named $\alpha$ and $\beta$ endosulfines [11]. These two forms differ by their isoelectric points, the $\beta$ endosulfine being more basic [22]. Unpublished data suggest that they also differ by their molecular size, the $\beta$ form being significantly smaller than the $\alpha$ form. Indeed, the latter elutes from gel filtration columns in the volume of small proteins, while $\beta$ endosulfine behaves in gel filtration systems like small or medium sized peptides. The ability of $\beta$ endosulfine to induce insulin release from a beta-cell line in culture at concentrations that are active on the receptor was clearly established [11]. For technical reasons, it has not been possible, until now, to determine whether the same holds true for the $\alpha$ form. On the other hand, the comparison between the affinities of the two forms towards the receptor site was possible, although precise figures are not yet available. From the quantity of $\beta$ endosulfine, roughly computed from ultra violet absorbance, we were able to determine that the affinity of the peptide present in the binding experiments was in the nanomolar range (unpublished data), similar to unlabelled glibenclamide. In contrast, the same calculation yielded an affinity in the micromolar range, or lower, for the $\alpha$ form. The conclusion that may be drawn from these data is that $\beta$ endosulfine appears as the biologically competent molecule, having a nanomolar affinity similar to that of most of the known regulatory peptides (peptide hormones or locally acting peptides), whereas, with its higher molecular size and its lower affinity, $\alpha$ endosulfine may be seen as a precursor of the $\beta$ form. This hypothesis should, however, be confirmed by isolating sufficient amounts of $\beta$ endosulfine for determining its primary structure. From the purification data, it was possible to calculate that $\alpha$ endosulfine is present at roughly $2 \mu \mathrm{mol}$ per $\mathrm{kg}$ porcine brain. This is comparable to the concentration $(4 \mu \mathrm{mol} / \mathrm{kg})$ of a classical neurotransmitter such as serotonin [23].

The structural data obtained on pure $\alpha$ endosulfine presented in this report clearly indicated that this molecule strongly resembles a small protein, ARPP-
19 , previously isolated from bovine brain as a substrate for cyclic AMP-dependent protein kinase [20]: the apparent molecular mass of both molecules in PAGE are about $19 \mathrm{kDa}$, whereas the actual molecular mass is in the $13 \mathrm{kDa}$ range $(12,353$ for bovine ARPP-19, 13,196 for porcine $\alpha$ endosulfine). From the $\alpha$ endosulfine structure determined so far (72 amino acids), it appears that $82 \%$ are identical in the bovine ARPP-19 sequence. On the other hand, $18 \%$ of the known $\alpha$ endosulfine structure differs from the equivalent moiety in bovine ARPP-19. Two hypotheses are compatible with these observations: $\alpha$ endosulfine and ARPP-19 may be the same molecular entity, the differences observed in amino acid sequences reflecting the difference in animal species (porcine $v s$ bovine origin). Alternatively, the two entities are different, with large overlaps in molecular structure. Many examples are available of proteins with similar or identical amino acid sequences in a large portion of their structures, but which derive from different genes and have separate biological roles. Since endosulfine was detected in every animal species tested so far including rats [10], sheep [11] and swine (the present report), it appears that at least the active moiety of endosulfine was largely conserved during evolution. Molecular cloning of the cDNAs coding for endosulfine(s) and ARPP-19 from several animal species is necessary to answer this important question.

In the absence of these essential data, we can only speculate on the relationship between these endogenous ligands and their roles in biological regulation. From that viewpoint, it is noteworthy that a variant of ARPP-19, ARPP-16 is preferentially present in some areas of the CNS such as the substantia nigra. Although the binding sites for sulphonylurea are widely distributed in the CNS, particularly in the cortex, a notably high concentration of these sites was found in the substantia nigra $[24,25]$, indicative of a possible role for K-ATP channels in controlling the functions of these neurons [26]. The presence in the same zone of high concentrations of a molecule of the family of these potential endogenous ligands further substantiates the idea that, in the CNS, the endosulfine/receptor/K-ATP channel ensemble represents the molecular basis for a regulatory mechanism, the precise nature of which remains to be determined. If, as previously suggested [11], endosulfine(s) represent the natural regulator(s) of K-ATP channels, their biological roles should differ depending on the tissues 
which express these specific channels, including pancreatic beta-cells [7], CNS [24, 25], peripheral tissues [27] or heart [28].

A recent report [29] shows the primary structure of the sulphonylurea receptor, distinct from the $\mathrm{K}$ ATP channel [30]. More information is needed on the structure of the endogenous ligand(s) of this regulatory complex. This report represents the first clue to this issue.

Acknowledgements. We would like to thank Dr. M. Becchi (Service Central d'Analyse, CNRS) for his help in running the mass spectrometry experiments and the Fondation pour la Recherche Médicale for a grant to A.V.-V

\section{References}

1. Loubatières A (1977) Effects of sulfonylureas on the pancreas. In: Volk BW, Wellman KF (eds) The diabetic pancreas. Plenum Press, New York, pp 489-515

2. Kaubisch N, Hammer R, Wollheim C, Renold AE, Offord RE (1982) Specific receptors for sulfonylureas in brain and in $\beta$-cell tumors of the rat. Biochem Pharmacol 31: 1171-1174

3. Ashcroft SJH, Ashcroft FM (1992) The sulfonylurea receptor. Biochem Biophys Acta 1175: 45-59

4. Ashford MLJ, Sturgess NC, Cook DL, Hales CN (1986) K channels in insulin-secreting cell line: effects of ATP and sulfonylureas. In: Atwater I, Rojas E, Soria B (eds) Biophysics of the pancreatic B-cells. Plenum Press, New York, pp 69-76

5. Cook DL, Hales CN (1984) Intracellular ATP directly blocks $\mathrm{K}^{+}$channels in pancreatic $\beta$-cells. Nature $311: 271-$ 273

6. Ashcroft FM, Harrisson DE, Ashcroft SJH (1984) Glucose induces closure of single potassium channels in isolated rat pancreatic $\beta$-cells. Nature 312: 446-448

7. Ashcroft SJH, Ashcroft FM (1990) Properties and functions of ATP-sensitive K-channels. Cell Signal 2: 197-214

8. Lupo B, Bataille D (1987) A binding site for ${ }^{3} \mathrm{H}$-glipizide in the rat cerebral cortex. Eur J Pharmacol 140: 157-169

9. Mourre C, Ben Ari Y, Bernardi H, Fosset M, Lazdunski M (1989) Antidiabetic sulfonylureas: localization of binding sites in the brain and effects of the hyperpolarization induced by anoxia in hippocampal slices Brain Res 486: 159164

10. Virsolvy-Vergine A, Brück M, Dufour M, Cauvin A, Lupo B, Bataille D (1988) An endogenous ligand for the central sulfonylurea receptor. FEBS Lett 242: 65-69

11. Virsolvy-Vergine A, Leray H, Kuroki S, Lupo B, Dufour M, Bataille D (1992) Endosulphine, an endogenous peptidic ligand for the sulfonylurea receptor: purification and partial characterization from ovine brain. Proc Natl Acad Sci USA 89: 6629-6633

12. Mutt V (1978) Hormone isolation. In: Bloom SR (ed) Gut hormones. Churchill Livingston, London, pp 21-27

13. Sillard R, Rökaeus A, Xu Y, Carlqvist M, Bergman T, Jörnvall H, Mutt V (1992) Variant forms of galanin isolated from porcine brain. Peptides 13: 1055-1060
14. Laemmli UK (1970) Cleavage of structural proteins during the assembly of the head of bacteriophage T4. Nature (London) 227: 680-686

15. Bradford MM (1976) A rapid and sensitive method for the quantitation of microgram quantities of protein using the principle of dye-binding. Anal Biochem 72: 248-254

16. Vincent C, Denoroy L, Revillard JP (1994) Molecular variants of $\beta_{2}$-microglobulin in renal insufficiency. Biochem $\mathrm{J}$ 298: $181-187$

17. Hewick RM, Hunkapiller MW, Hood LE, Dreyer WJ (1981) A gas-liquid solid phase peptide and protein sequenator. J Biol Chem 256: 7990-7997

18. Esch FS (1984) Polypeptide microsequence analysis with the commercially available gas-phase sequencer. Anal Biochem 136: $39-47$

19. Dessen P, Fondrat C, Valencien C, Mugnier C (1990) BISANCE: A French service for access to biomolecular sequence databases. CABIOS 6: 355-356

20. Girault JA, Horiuchi A, Gustafson E, Rosen N, Greengard P (1990) Differential expresion of ARPP-16 and ARPP-19, two highly related CAMP-regulated phosphoproteins, one of which is specifically associated with dopamine-innervated brain regions. J Neurosci 10: 1124-1133

21. Horiuchi A, Williams K, Kurihara T, Nairn A, Greengard P (1990) Purification and cDNA cloning of ARPP-16, a cAMP-regulated phosphoprotein enriched in the basal ganglia, and of a related phosphoprotein, ARPP-19. J Biol Chem 265: 9476-9484

22. Virsolvy-Vergine A, Lupo B, Bataille D (1991) Ligand endogène du récepteur des sulfonylurées. In: Selam JL (ed) Journées de diabétologie 1991. Flammarion, Paris, pp 171-184

23. Ferstrom JD (1984) Tryptophan availability and serotonin synthesis in rat brain: effects of experimental diabetes. In: Schlossberger HG, Kochen W, Linzen B, Steinhart H (eds) Progress in tryptophan and serotonin research. de Gruyter, Berlin, pp161-172

24. Mourre C, Widmann C, Lazdunski M (1990) Sulfonylurea binding sites associated with ATP-regulated $\mathrm{K}^{+}$channels in the central nervous system: autoradiographic analysis of their distribution and ontogenesis, and of their localization in mutant mice cerebellum. Brain Research 486: 159-164

25. Miller JA, Velayo NL, Dage RC, Rampe D (1990) High affinity ${ }^{3} \mathrm{H}$-glibenclamide binding sites in rat neuronal and cardiac tissue: localization and developmental characteristics. J Pharmacol Exp Therap 256: 358-364

26. Schmid-Antomarchi H, Amoroso S, Fosset M, Lazdunski $\mathrm{M}(1990) \mathrm{K}^{+}$channel openers activate brain sulfonylureasensitive $\mathrm{K}^{+}$channels and block neurosecretion. Proc Natl Acad Sci USA 87: 3489-3492

27. Lebovitz HE, Feinglos MN, Bucholtz HK, Lebovitz FL (1977) Potentiation of insulin action: a probable mechanism for the anti-diabetic action of sulfonylurea drugs. J Clin Endocrinol Metab 45: 601-604

28. Nichols CG, Lederer WJ (1991) Adenosine triphosphatesensitive potassium channels in the cardiovascular system. Am J Physiol 261:H1675-H1686

29. Aguilar-Bryan L, Nichols CG, Wechsler SW et al. (1995) Cloning of the beta cell high-affinity sulfonylurea receptor: a regulator of insulin secretion. Science 268: 423-426

30. Ashford MLJ, Bond CT, Blair TA, Adelman JP (1994) cloning and functional expression of a rat heart $\mathrm{K}_{\mathrm{ATP}}$ channel. Nature 370: 456-459 